\title{
Youth unemployment in South Africa
}

\section{A theological reflection through the lens of human dignity}

\section{Anita Cloete $^{1}$}

\begin{abstract}
This article pays attention to youth unemployment as one of the most serious socioeconomic challenges in South Africa. The nature of unemployment in South Africa is followed by a discussion on the interconnectedness between unemployment and poverty. The psychological and theological meaning of work is discussed in short, followed by the psychological effect of unemployment. In order to indicate how unemployment undermines human dignity, certain theological themes on human dignity are outlined. The final section explores ways in which the church could assist in affirming human dignity in the context of unemployment.
\end{abstract}

Key words: Youth, unemployment, human dignity, church.

"Unemployment remains the biggest thief of hope amongst young people". 2

\section{Introduction}

Unemployment is mostly described as an economic issue, but it's argued here that unemployment poses a threat to human dignity and should therefore be a theological concern.The focus on youth unemployment is motivated by the fact that young people are the biggest cohort of new job seekers and are therefore the most vulnerable group with regard to unemployment. Furthermore little research has been done, especially in South Africa, on youth unemployment from a theological perspective. Unemployed here refers to those who are available for work and are looking for work, but cannot find paid work. The focus is thus not on voluntary unemployment, but rather on involuntary unemployment. The article will first explore the problem of unemployment, utilising other discipline like psychology to interpret the effect thereof. The normative focus is through the lens of a theological perspective on human dignity. In light of the severity and the cause and effect of the problem and the normative perspective, certain pragmatic suggestions is made as to how the church could be an agent of speaking out against inhumane conditions and relations and restore and cherish human dignity in the context of unemployment.

1 Dr. Anita Cloete is a Senior Lector In the Department Practical Theology \& Missiology,Faculty of Theology, at the University of Stellenbosch. She can be contacted at acloete@sun.ac.za

2 Ramphele, M. Steering by the Stars: Being Young in South Africa. (Cape Town: Tafelberg Publishers 2002) 12. 


\section{Youth unemployment in South Africa}

Lam, Leibrandt and Mlatsheni point out that South Africa is an important case study for youth unemployment, although research on youth unemployment in South Africa is new. ${ }^{3}$ According to Cochrane and West, youth and those with lower skill levels are most affected by the unemployment situation in South Africa. Statistics from different studies confirm the challenge of youth unemployment in South Africa. ${ }^{4}$ A study by Community Agency for Social Enquiry (CASE) in 2000, more than 12 years ago, indicates that the youth perceived unemployment as the biggest problem facing them. ${ }^{5}$ Unfortunately the picture did not change as Baker confirms that three-quarters of all unemployed persons in South Africa are younger than 35 years and $65 \%$ of the unemployed have never held a job. ${ }^{6}$ According to Stats SA 2012, the unemployment rate for the first quarter of 2010 is $25.2 \%$ (according to the narrow definition) and approximately $37 \%$ according to the broad definition. ${ }^{7}$ The 2014 Stats SA confirms the continuous high unemployment rate of $67,7 \%$ amongst the age group 15-34 (youth). ${ }^{8}$ The structural nature of unemployment is pointed as one of the main reasons for the increase in long-term unemployment that rose from 2,6 million in 2008 to 3,4 million in 2014, while the unemployment rate is $25,4 \%$ according to the narrow definition, which excludes the discouraged job-seekers. ${ }^{9}$

Although there are various reasons for youth unemployment such as population growth, lack of experience, inappropriate ways of searching for a job, and lack of career guidance in schools, the unemployment rate for first-time job-seekers in South Africa is unacceptably high. Young people are beginning to feel a sense of alienation from the larger society and a sense of betrayal by the government, because they realize that their lives have not changed for the better since 1994. A study in the Limpopo province confirms that the majority of young people are concerned that the government is not doing enough to create jobs for them. Although they served as "foot soldiers" during the apartheid struggle, they have been forgotten now that freedom has been achieved. ${ }^{10}$ Youth has been on the forefront of the struggle for

\footnotetext{
${ }^{3}$ Leibbrandt, D. L.M.,\& Mlatsheni, C. Education and Youth Unemployment in South Africa. Working Papers Series No 22. South African Labour and Development Research Unit, (UCT: Cape Town 2008), 1-2.

4 Cochrane, J. R. \& West, G. O. The Three-Fold Cord: Theology, Work and Labour. (Cape Town: Cluster Publication 1991), 34.

5 Youth 2000. A National Study of Youth in South Africa. http//www.director@case.organ.za/htm/ yo2000.htm

6 Barker, F. The South African Labour Market:Theory and Practice. (Pretoria: Van Schaik 2007), 183.

7 Stats SA, 2002. Labour force Survey, February 2002. Pretoria: Statistics South Africa.

8 Stats SA 2014. Quarterly Labour Force Survey, Quarter 3. 2014. http:/ beta2.statssa.gov.za, Visited 2015/01/16.

9 Stats SA 2014

${ }^{10}$ Mokgohloa, D., Views and Experiences of Unemployed Youth Graduates: A Case Study of the Polokwa-
} 
freedom and participated in demonstration on grassroots level in protest against the apartheids regime and many lost their lives in the process.

In order to understand the challenge of unemployment better, specifically in South Africa, the nature of unemployment will be discussed in short.

\section{The nature of unemployment in South Africa}

Unemployment in South Africa has an indisputable structural or systemic character. Structural unemployment implies the overall inability of an economy to provide employment for the total (or potential) labour force, even at the peak of its economic cycle. Needless to say, due to its nature, structural unemployment is the hardest to address. Unemployment is also much higher amongst the poor and is therefore mentioned as one of the four poverty traps inherent in the socio-economic situation since 1994. ${ }^{11}$ Although the South African economy has grown fast since adopting the neo-liberal economic system, it did not result in generating employment. The adoption of neo-liberal globalism and free-trade policies exposed South Africa to the import of cheap products and the well-intended labour legislation of the ANC government contributed to unemployment in South Africa. He concludes that because of this situation " $[\mathrm{t}]$ he South African economy today has much more of a third world character than it had in 1994". ${ }^{12}$

Du Plessis and Smith explain that employment has fallen due to the relative increase in demand for skilled labour, which imply a decrease in the demand for unskilled labour with the drive to improve its international competitive position. ${ }^{13}$ This is thus in line with the statement made earlier that young people and unskilled people are mostly affected by unemployment. In contrast with the fact that unskilled people struggle to find employment, the unemployment rate amongst educated people (skilled people) is also increasing in South Africa. Mokgohloa emphasises the fact that although poor education is significant contributing factor to unemployment, graduate unemployment is also on the increase in our country. ${ }^{14}$ Other characteristics of unemployment is that it is not homogenously spread amongst the different population groups as black and female youths have less access to employment. ${ }^{15}$ Education also has a recognised role in unemployment as with poor educa-

ne area, Limpopo Province South Africa. (M Phil thesis: Stellenbosch University 2006), 38.

11 Terreblance, S. A History of Inequality in South Africa 1652-2002. (Pietermaritzburg: University of Natal Press 2005), 372-374.

12 Terreblance. S, Lost in Transformation: South Africa search for a new future since 1986. (Sandton: KMM Review Publishing Company 2012), 107.

13 Duplesis, S, Smith, B, South Africa's Growth Revival After 1994. Journal of African Economies 16. no 5 (2007), 668-704.

14 Mokgohloa, Graduate Unemployment, 15.

${ }^{15}$ Mlatsheni, C, Rospabé, S, Why Youth Unemployment is high and unequally spread in South Africa? 
tion it is difficult and even impossible to find employment. ${ }^{16}$ Unemployment thus reflects other social challenges like racial and sexual inequalities in our country and could also be linked to poverty. The relationship between unemployment and poverty as well as the possible cause and effects of poverty on people will be the focus of the following section.

\section{Unemployment and poverty}

The link between unemployment and poverty is described by Fourie as 'bi-directional causality' since unemployment causes poverty and poverty contributes to unemployment and its persistence. ${ }^{17}$ The perceptive that poverty persists not only because of a scarcity of resources, because some societies have inefficient economic systems, or lack of natural resources, or because poor people lack ambition is relevant for this article. ${ }^{18}$ Poverty is a product of human social relationships. According to this perspective the social aspects of relationships set the structure of economic exchange. The way people assign and distribute things of value, depends both on how integrated and segregated their relationships are and how powerful they are in relation to one another. There is also a certain stigmatisation attached to, stereotyping of and prejudice towards poor people because poverty is associated with such problems as lack of hygiene, illness, disease and lack of education, and so on. These prejudices lead to distance between the poor and the rich and this distance keeps the distorted relationships with their unequal distributions of resources and power intact.

Poverty is thus much more than a lack of access to resources to meet basic needs. Poverty is also a symptom of power inequalities. In this kind of relationship the powerful have the freedom to engage with or to exclude. Poverty is not only about a lack of access to basic services, but of being excluded from the interaction, decision-making process and, most of all, the exchange of goods in economic processes. Therefore the plight of the poor is best understood on their own terms. Poverty inflicts physical, psychological and spiritual pain in people of all ages who strive for wellness and resist the oppressive burden of destitution. In the discussion of the effect of unemployment it will become clear that unemployment influences not only the personal well-being of the individual, but also the wellness of

Working Papers. (University of Cape Town2002), no 02, 65.

${ }^{16}$ Honwana, A, The Time of Youth: Work, Social Change and Politics in Africa. (Virginia: Kumarian Press 2012), 51.

17 Fourie, F.C.V.N, The South African unemployment debate: three worlds, three discourses. Working Paper Series, (2011) no 63, 84.

18 Carr, S. C. and Sloan, T. S, Poverty and Psychology: From Global Perspective to Local Practice. (New York: Plenum Publishers 200). 147-149. 
the broader society. Wellness entails personal, relational, and collective wellness. Wellness could be defined as a positive state of affairs achieved by the simultaneous and synergistic satisfaction of personal and collective needs. Citizens however, need public resources to pursue private inspirations, implying that there is no caring without justice and no justice without caring. ${ }^{19}$

In summary form, unemployment which often results in and causes poverty is not an individual but a collective problem. People are poor because others are rich; it is two sides of the same coin. Unemployment and poverty are results of an economic system that seems to exclude people from participating in economic activities and results from the power relations between "the haves and have not's", those in the centre and those on the margins (periphery).The distance created between these different groups (rich and poor) are described best by inequality which is characterized by distorted power relations and are often kept intact by stigmatisation and stereotyping. In order to understand the effect of unemployment better I shall pay attention in the following section to what work means to people. First the psychological meaning of work will be discussed, followed by a theological reflection of work mainly from a Protestant work ethic perspective.

\section{The meaning of work from a psychological and theological perspective}

Most societies regard work as one of the most important aspects of being human. From a young age children are asked: What would you like to become one day? Implying: What kind of work would you like to do? ${ }^{20}$ Likewise, if we meet an adult the question will be: What do you do? The answer to this question offers instant clues to income, social status and lifestyle. Some theorists suggest that a person's worth is calculated in terms of the money they earn through work. ${ }^{21}$ Work serves various social and interpersonal functions and offers people opportunities to satisfy psychological needs. Work can provide social contact; friendship and support as well as opportunities for gaining recognition. ${ }^{22}$ Furthermore work can help young people enter the adult world. Through work people can provide for themselves and their families. A job can engender a sense of purpose and value and shape a person's identity and self-esteem. ${ }^{23}$ Although so many South Africans who want to work, do not have work, the theological understanding of work also

19 Prilleltensky I. Poverty and Power. In Carr, S. C. \& Sloan, T. S, Poverty and Psychology: From Global Perspective to Local Practice. (New York: Plenum Publisher 2003) 22-24.

${ }^{20}$ Honwana, The time of Youth (2012), 29.

${ }^{21}$ Gonzo, W and Platter, I. E, Unemployment in an African Country: A Psychological Perspective. (Namibia:University of Namibia Press 2003),11.

${ }^{22}$ Møller, V. The Quality of Life in Unemployment. (Pretoria: HSRC Publishers 1993), 5.

${ }^{23}$ Gonzo, Unemployment in an African Country. (2003), 11. 
points to work as an integral part of being human. Work is an essential part of God's original purpose for human life at creation. Even if there was no sin, there would be work. Through their work, human beings represent God's own wise and caring rule over creation, and so they are the "image" of God in and through their work. ${ }^{24}$ While work is sometimes burdensome because of $\sin$ (Gen 3), it was never regarded as an option. ${ }^{25}$ Furthermore, there is a connection between work and reward (Luke 10: 7). We tend to identify ourselves in terms of our work and because of the centrality of work in our lives; Christian traditions came to affirm that we earn a living as part of our response to God. Work is more than just a commodity defined by the workplace and distributed by the market rules. Work has to do with the existence of people, being part of communal and personal well-being. Peter Mayhew corroborates that people have a need to work and that work gives identity and status. It seems that there is correlation between the theological understanding of work and the psychological meaning of work ${ }^{26}$ Although both perspectives (theological and psychological) indicate that work gives structure and meaning to people's lives, many South Africans, especially young people, are confronted with massive unemployment.

\section{The psychological effect of unemployment}

The psychological effect of unemployment is viewed as important for the discussion as it helps us to understand how people experience and respond to unemployment as human beings. Therefore we need to look behind the statistics of unemployment at the experience of the unemployed.$^{27}$ The economic effect of unemployment is mostly emphasized while the psychological effect is neglected. It is, however, of utmost importance to understand the psychological effect of unemployment on people, as being unemployed influences the total well-being of a person in a very negative, almost destructive way. ${ }^{28}$ Although people show resilience in devastating conditions, the negative psychological effects of unemployment are well-described by a broad body of research. The conventional or negative approach to unemployment is closer to the South African reality, which departs from the basic assumption that unemployment is bad at the macro-sociological and individual level and employment is the desired state. Unemployment puts mental health at risk beyond reasonable doubt as most unemployed people show a constant decrease in overall

${ }^{24}$ Mayhew, P, Unemployment under the Judgement of God. (Great Britain: Churchman Publishing Ltd 1985) 9.

${ }^{25}$ Crook, R. H, An Introduction to Christian Ethics. (New Jersey: Pearson Prentice Hall 2007), 273.

${ }^{26}$ Mayhew, Unemployment under the Judgement of God. (1985),9.

${ }^{27}$ Wilson, F and Ramphele, M. Uprooting Poverty: The South African challenge. (Cape Town: David Phillip 1989),93.

${ }^{28}$ Carr and Sloan, Poverty and Psychology (2003), 77. 
life satisfaction, general well-being and self-esteem, and symptoms of depression, especially if they are unemployed for a long period. ${ }^{29}$ Other psychological effects include increased anxiety, lack of self-confidence, pessimism, fatalism, alcoholism, apathy, suicide, as well as stress-related psychosomatic disorders such as headaches, stomach ulcers, dermatitis, bronchitis and heart diseases. ${ }^{30}$

Most of the time unemployment is also the cause of other social ills like crime, divorce, suicide, and child-maltreatment. ${ }^{31}$ The link between unemployment and poverty has also been established and poor people suffer from nihilism, a psychological state indicated by the lack of meaning and purpose in life, as poor people lose their values and no longer believe in themselves and the world. ${ }^{32}$ This state contributes to the immobilisation of the poor because they feel that nothing can be done, that there is no course of action to take, that nothing is possible. Work seems to give not only structured activity, income and social status, but also a sense of self-worth and belonging to a community in which the person feels wanted and needed. Unemployment however, has the opposite effect, namely powerlessness, self-estrangement, isolation and meaninglessness. ${ }^{33}$

Research indicates that there is a difference between the older and younger jobless. ${ }^{34}$ One supposes that older people have worked in the past, while younger people (three-quarters) in the South Africa context never held a job, and therefore do not qualify for unemployment insurance benefits. Youngsters do not have sources of support other than their families and mostly turn to crime and anti-social behaviour. Experiences of unemployed young people include lowering of self-esteem, a feeling of uselessness and a sense that life may be meaningless. ${ }^{35}$ Youth unemployment has a negative effect on the individual and the family, but also on the broader community in the form of serious economic and social consequences. This includes economic welfare, production, and erosion of human capital, social exclusion, crime and social instability. ${ }^{36}$ The rise in educated unemployment in South Africa is definitely a big concern, as young people tend to view education as useless and not important. Youth has an unimagined future due to the lack of employment, which means that their

${ }^{29}$ Carr and Sloan, Poverty and Psychology (2003), 89.

${ }^{30}$ De Witte, H., Rothmann, S., Jackson, L.T.B, The Psychological Consequences of Unemployment in South Africa. SAJEMS 15, no. 3 (2012), 247.

${ }^{31}$ Allen, S, Watson, A. \& Wood, S. The Experience of the Unemployed. (London:The Macmillan Press Ltd 1986), 16.

${ }^{32}$ Carr and Sloan, Poverty and Psychology (2003), 77

${ }^{33}$ Fagin, L. \& Little, M. The Forsaken Families: A timely and disturbing report on the effects of unemployment on family life in Britain. (Great Britain: Richard Clay Ltd 1984),37.

${ }^{34}$ Møller, V. The Quality of Life in Unemployment. (1992), 3.

${ }^{35}$ Barker, F. The South African Labour Market:Theory and Practice. (Pretoria:Van Schaik2007), 182.

${ }^{36}$ Van der Berg, S. Confronting unemployment in South Africa. Occasional papers no 6. (Stellenbosch Economic Project 1992), 3. 
future dreams are consumed with a desire to survive today. "In Africa young people in waithood live mainly in the present. The distant future is difficult to envision in the face of the daily social and economic hardships" ${ }^{37}$ In such a context dreaming of a better tomorrow becomes a luxury and being a responsible citizen contributing to the countries welfare are not really possible. This further implies that transition from youth to adulthood is extended and youth have to create new forms of transition in order to make their lives meaningful. Before indicating how unemployment poses a potential threat to human dignity, a theological perspective on human dignity is offered, followed by proposals on how the church could play a significant role in restoring human dignity in the context of unemployment.

\section{Theological perspective on human dignity}

Although the notion of human dignity has a very rich theological tradition, only a few theological themes pertaining to human dignity will be highlighted here. Dignity literally means a sense of worth. From a Christian point of view, dignity assumes identity. Identity answers the question: "Who am I?" while dignity answers the question: "What am I worth?" ${ }^{88}$ The Bible makes identity the prior question and teaches that both the creation and redemption of humanity are acts of God's grace. True dignity thus includes a sense of identity (a sense of self, who one is) and a sense of worth or value. Samuel describes human dignity as "...where people discover a sense of self-worth, self-acceptance and a sense of having something to contribute to the world and others ... where people are able to make their own contribution to the life of the community, especially as participants in decisions which affect them and their family, the community, in religious matters and political structures ...". 39

Sugden notes that this identity and value or worth that constitutes our human dignity, is conferred by God and therefore its measure and norm is to be discovered not in social conventions, but in the pattern of God's actions towards humankind in the creation and redemption in Christ. ${ }^{40}$ Claassens concurs with this view that human dignity is a gracious gift from God. In other words, God bestowed dignity on humans without explanation or any possibility that they could deserve it in any way. ${ }^{41}$ The modern concept of human dignity stands remarkably exposed as human dignity now inheres solely in the human being's own possessions and achievements.

${ }^{37}$ Honwana, The time of Youth (2012), 30.

${ }^{38}$ Sudgen, C. What is Good about Good News to the Poor? In Samual, V. \& Sudgen, C. (ed) Mission as Transformation: A Theology of the Whole Gospel. (Oxford: Regnum 1999) 239.

39 Samuel, V. \& Sudgen, C. (ed) Mission as Transformation: A Theology of the Whole Gospel. (Oxford: Regnum 1999), 239.

${ }^{40}$ Sudgen. What is Good about Good News to the Poor? (1999), 239.

41 Claassens, L. J. M. Human dignity in the prophetic tradition: Upholding human worth in a context of dehumanization. Nederduitse Gereformeerde Teologiese Tydskrif. 52 no 1( 2011), 34-44. 
This understanding of human dignity is thus in sharp contrast to the Christian theological view thereof which postulates that human dignity is something that no one can achieve, but is granted by God and is therefore God's activity and does not depend on human ability. This also implies that we are equal as human beings despite apparent differences like race, gender and class, because human dignity does not depend on any human achievement or status, but is bestowed on all humans by God. Equality therefore does not imply sameness as human beings are unique, but rather refers to our standing before and in relation to God. Human dignity further does not depend on certain prerequisites but rests solely on God's graceful dealings with human beings and therefore includes all and does not exclude anyone.

Vorster extends the view of human dignity as gift from God by arguing that humans belong to God, which entails that persons are entitled to God-given rights like the right to life and freedom. Vorster sees the right to dignity as the most basic property of human persons, whereby humans are worthy and should therefore be treated with respect, because they stand in a special relationship to God. ${ }^{42}$ Humans are representatives of God on earth through the imago Dei, which expresses the creational status in relation to God, fellow human beings and the earth. Human dignity is thus not only a gift undeservingly bestowed on human beings, but also has implications for how we live before God. In that sense human dignity is not only a right, but also a responsibility in communion with other human beings.

In line with this understanding of human dignity, as implying rights and responsibilities, is the notion of human dignity as communal and relational. Claassens describes it as follows: "...human dignity is inherently relational rather than individualistic in its orientation". We have dignity in relation to others, as others recognise our dignity by treating us with respect and vice versa. ${ }^{43}$ Fischer explains that the social world is based on recognition and respect. Recognition refers to social belonging and social status; whereas respect has to with the claims and rights a person has on the basis of social belonging. 44 "Recognition implies that there is something that precedes recognition and is the reason for the recognition. Therefore not recognising human dignity is a moral mistake". ${ }^{45}$ Koopman echoes this understanding of human dignity when he states: "Dignity is served where there is care for and justice to the vulnerable, where there is a communion of interdependency, reciprocity, mutuality and participation, and where there is freedom to live a life of decision-making, worth, self-actualisation,

${ }^{42}$ Vorster, N. A Theological perspective on human dignity, equality and freedom. Verbum et Ecclesia 33 no 1 (2012), 3.

43 Claassens. Human dignity in the prophetic tradition. (2011). 39.

${ }^{44}$ Fischer, J. The social recognition of human dignity. Journal of International de Bioéthique 21, no3 (2010), 45-49.

45 Fischer, The social recognition of human dignity. (2010), 46. 
service and the space to pursue broader and specific goals". ${ }^{46}$ Dignity thus has to do with who we are and our participation and contribution to the common good for all. Human dignity therefore emphasizes solidarity with other human beings and implies interdependence and mutual need. Our human dignity is therefore upheld and confirmed in communion with our "co-humanity" and co-existence. ${ }^{47}$ Human dignity is also expressed in human beings' quest for a meaningful life. Wherever quality of life is enhanced, human dignity is upheld and fostered. ${ }^{48}$

\section{Unemployment and human dignity}

Human dignity is not an abstract, theoretical concept. On the contrary, human dignity has huge implications for our individual and communal life as human beings. Mattson and Clark refer to human dignity as a lived experience when they describe human dignity as follows: "Dignity is something to be realized through the human experience of autonomous choice in the domain of the political; happiness, well-being, self-esteem, and psychological integrity in the domain of the psychological; of belonging to a group or culture, adhering to a set of norms, with access to approval, respect and recognition in the domain of the social; and of access to security, food, shelter and physical integrity in the domain of the material". ${ }^{49}$ A dignified existence is therefore characterised by quality of life. As dignified beings we therefore strive for living conditions that reflect, respect, actualise and confirm our human dignity. Vorster is also of the opinion that "the right of life implies that all people have the right to the means necessary for subsistence, because it is a fundamental prerequisite for a dignified life". ${ }^{50}$ Unemployment however, prevents many South Africans to live lives that reflect and actualise and confirm their dignity as human beings. The section on the psychological and theological meaning of work indicates that work is more than just earning money, but gives people opportunities to grow and develop as human beings and be creative. Work confirms our human dignity as it gives opportunities to provide for ourselves and others, social interactions and meaningful living. Unemployment on the other hand deprives people from providing for themselves in their most basic needs like shelter, food and health. Poverty which in most cases causes unemployment makes people doubt their own worth and potential, puts mental well-being at risk and makes people lose hope for

${ }^{46}$ Koopman, N. Human dignity in the context of globalisation. In Boesak, A. \& Hansen. (eds). Global crisis, global challenge, global faith. An ongoing response to the Accra Confession. (Stellenbosch: Sun Press 2013) 6.

47 Louw, D. Network of the Human Soul. (Stellenbosch: Sun Press 2012) 163-166.

${ }^{48}$ Louw, D. Network of the Human Soul. (2012),165.

${ }^{49}$ Mattson, D., J., Clark, S. G. Human dignity in concept and practice. Policy Science. 44 (2011), 309.

${ }^{50}$ Vorster, A Theological perspective on human dignity, equality and freedom. (2012), 6 
the future. Unemployment excludes people from contributing to the common good through economic activity. The effect of unemployment results in a situation where people are divided and separated from each other along economic lines, especially in South Africa, where some have more than what they need and others have almost nothing. Stereotyping and stigmatisation keeps this distance between people intact. The distance referred to here is not mere physical distance, but has to do with not recognising and respecting people as fellow human beings. In other words, seeing them as less human and treating them accordingly.

Human dignity as a gracious gift bestowed on all human beings, however, binds us together as human beings and situations like unemployment and poverty which leads to distance, isolation and alienation between people, is in conflict with confirming and respecting human dignity. The communal characteristic of human dignity further implies that in a context where so many youngsters are uneducated, unemployed and live in poverty it is not only their human dignity that is scarred but the human dignity of a nation is at stake and needs restoration. Scholars agree that human dignity belongs to the human rights discourse ${ }^{51}$ Put differently, human rights could be viewed as a means to the end of realising and making human dignity visible in the lives of people. Today, however, we face a paradoxical situation where human dignity is affirmed as a fundamental principle by the constitution in South Africa and therefore people do have a right to employment, but at the same time numerous social challenges like unemployment, put human dignity and well -being at risk. Although the state does have an enormous role in creating conditions where human dignity is upheld, recognised and respected, I would like to point out in short what the role of the church could entail, specifically with regard to unemployment and human dignity.

\section{Churches' contribution in restoring human dignity in the context of unemployment}

The previous section indicated how unemployment is posing a serious threat to human dignity. Claassens argues that it is in a context of dehumanization that the conversation of human dignity is most urgent..$^{52}$ Although job creation seems to be the logical answer to address unemployment, it is also the hardest to achieve, even by a government and a growing economy. In a study by Cloete on churches' involvement in dealing with unemployment, it is found that churches do not seem to have the capability

\footnotetext{
${ }^{51}$ Botman, H.R., Human dignity and economic globalization. In Botman, H.R., Sporre, K. Building a human rights culture. ( Falun: Högskolan Dalarna 2003) 25.

52 Claassens. Human dignity in the prophetic tradition. (2011), 36-39.
} 
and capacity to initiate and sustain developmental projects in this regard. ${ }^{53}$ Therefore I would like to suggest other contributions churches can make in this regard.

If we accept the perspective of Lemieux and Prattto that poverty is a product of human social relationships where values play a role in the distribution of value things and power, the church can most definitely play a role in taking the lead in determining the kind of values that are operating in our society today..$^{54}$ We are aware of the uneven and unjust distribution of power and opportunities in South Africa which results in a growing gap between rich and poor. This situation is certainly a cry for moral communities like churches to step in. The state and business sector express fears for a process of eroding social bonds, weakening social cohesion. According to Van der Ven, Dreyer and Pieterse the question is: "What holds society together? Is it money, bureaucracy, social security, human rights, culture, religion? There is a need in society on all levels for more discipline, more decent behaviour, more compliance with norms, more obedience to authorities, more emphasis on duties and obligations, more conformity to codes that people have agreed upon or been socialized into, more social control". ${ }^{55}$ I am sure that churches can take a leading role in helping to restore the moral fibre and social cohesion in our communities, which is currently under great pressure because of unemployment.

As mentioned in the discussion on the effect of unemployment, there is a certain stigmatisation, stereotyping and prejudice of poor people because poverty is associated with e.g., lack of hygiene, illness, disease and lack of education. This stigma originates from the modern view of human dignity, i.e. human dignity is accomplished by people through achievements, achievements that unemployed and poor people cannot accomplish because they are excluded from opportunities. Churches can help us to think and speak of the poor as people who are also created in God's image and therefore need to be treated with respect and dignity. There is a tendency to talk about them as "the other". The poor and also the unemployed are under suspicion, capable of violence and laziness. ${ }^{56}$ Van Aarde explains that this negative "ascribed" social identity originates from ignorance of understanding a culture of poverty as most people are not voluntarily unemployed or poor. ${ }^{57}$ This way of thinking and speaking of the poor and the unemployed is dehumanizing. It is therefore important that

${ }^{53}$ Cloete, A. L. Faith based Organisation and Unemployment: an Empirical Survey in the Paarl-Wellington Community. (UNISA: Unpublished Doctoral thesis 2007).

${ }^{54}$ Lemieux, A. F. \& Pratto, F. Poverty and Prejudice. (2003), 147.

55 Van der Ven, J, Dreyer, H. \& J. C. Pieterse. The Formation of Churches as Moral Communities. Praktiese Teologie in Suid-Afrika, 17 no 1 (2002), 109-111.

${ }^{56}$ Odendaal, M. Meditating on poverty: seeking guidance from the Psalms. Nederduitse Gereformeerde Teologiese Tydskrif (NGT) 45 no 2 (2004), 294.

57 Van Aarde, Armoedekultuur: Die Leefwêreld van die Nuwe Testament en die situasie in Suid-Afrika vandag. HTS Theological Studies. 52 no 4 (1996), 952. 
churches help and guide us to think and speak of the poor and the unemployed in more humane ways. God is with the poor in their struggle and therefore to speak of the poor, poverty and the unemployed in vague and absolute terms reduces God's presence. In this regard Van Aarde rightly argues that a Christian Community where the attitudes and behaviour is based on the gospel, the church should be a space where the disrespected poor identity is transformed from a no-body to a child of God. ${ }^{58} \mathrm{~A}$ humane and empowering view of the unemployed and poor could create a space where especially youth are seen as co-creators of their future and not merely objects of development programmes. This could break the cycle where poor people see themselves as dependent on help from outside or see themselves as valuable human beings and instrumental in changing their situation. Odendaal states: "God's presence creates a space where people can be more than their circumstances; more than their society judge them to be" ${ }^{59}$ Having this perspective poor people are not seen and experienced as a burden to society, but as co-participants of God's grace. This implies that it is not the poor or unemployed that needs us, but that we need each other. ${ }^{60}$ Due to the communal character of our human dignity both the rich and poor human dignity are being scarred and not appreciated. Lastly churches will have to speak out against economic policies that keep the status quo where the rich become richer and the poor become poorer and contribute to a situation where inequality is one of the most well-known characteristics of the South African society. Terreblanche correctly notes: "The churches played a strategic role in the struggle against apartheid. Why are the churches not conducting an open war on behalf of those that are undeservedly poor and against those that are undeservedly rich?" ${ }^{61}$

\section{Conclusion}

The churches' own theological understanding of human dignity and anthropology comes into play when we ask the question how churches can assist the unemployed, confirming their identity and self-worth (human dignity). Churches' role in social critique is also in question when it comes to a social challenge like unemployment. In other words, do churches have any idea what is happening in the current global economic system and how it affects humanity? These are challenges and fundamental theological questions churches will need to reflect upon and act on in their endeavour to help restore and affirm human dignity today specifically in the context of the unemployment of youth.

58 Van Aarde, Armoedekultuur ( 1996) 952

${ }^{59}$ Odendaal, Meditating on poverty (2004), 299.

${ }^{60} \mathrm{Van}$ H. Hancke, F.J. God's missional people reflecting God's love in the midst of suffering and affliction. Acta Theologica, Supplement 16 (2012), 95.

${ }^{61}$ Terreblance. S, Lost in Transformation (2012), 114. 